\title{
Responding to Globalization
}

William Twining

Follow this and additional works at: http:// digitalcommons.osgoode.yorku.ca/ohlj Review Essay

\section{Citation Information}

Twining, William. "Responding to Globalization." Osgoode Hall Law Journal 49.2 (2011) : 353-373.

http://digitalcommons.osgoode.yorku.ca/ohlj/vol49/iss2/6

This Review Essay is brought to you for free and open access by the Journals at Osgoode Digital Commons. It has been accepted for inclusion in Osgoode Hall Law Journal by an authorized editor of Osgoode Digital Commons. 


\title{
353
}

\section{Review Essay}

\section{Responding to Globalization ${ }^{1}$}

\section{WILLIAM TWINING ${ }^{2}$}

\begin{abstract}
ALMOST ANYONE INVOLVED WITH LAW-as practitioner, judge, reformer, scholar, or theorist - needs to confront the question, "What are the implications of globalization for my work?" Many go beyond that question to ask about the broader implications for a specialized field of law, their practice, the practice of law generally, legal theory, or the place of law in the world. It is widely acknowledged that globalization is not entirely new, but for the past thirty years the pace and extent of change associated with it have greatly accelerated. Not surprisingly, there have been debates about its nature and significance. An enormous literature has sprung up and is expanding rapidly but unevenly. There has, of course, been an intellectual lag between the actual phenomena associated with globalization and academic responses to them. Discussions explicitly in terms of globalization gathered momentum in the social sciences around 1990, especially in economics, international relations, normative political theory, and sociology. Academic law reacted rather slowly in comparison, breaking cover in the late $1990 \mathrm{~s}$. A sociologist of law, Boaventura de Sousa Santos was slightly ahead of the field with his Toward a New Common Sense in $1995 .^{3}$ The legal literature is now achieving critical mass,
\end{abstract}

1. This essay offers an approach to interpreting the growing literature on globalization and law by looking at Rafael Domingo, The New Global Law (Cambridge, UK: Cambridge University Press, 2010) 212 pages. It builds on and extends two books: William Twining, General Jurisprudence: Understanding Law from a Global Perspective (Cambridge, UK: Cambridge University Press, 2009) [Twining, GJP] and William Twining, Globalisation and Legal Scholarship (Nijmegen: Wolf Legal, 2011) [Twining, GLS].

2. Quain Professor of Jurisprudence Emeritus, University College London and Visiting Professor, Universtiy of Miami School of Law.

3. (New York: Routledge, 1995). 
especially if one includes internal criticisms of specialist fields-notably public international law and comparative law. These "rethinkings" have not necessarily been attributed to globalization as such. Rafael Domingo's The New Global Law provides an opportunity to reflect on some trends in the legal literature. Although the book is part of a series the purpose of which is to clarify and improve the theoretical foundations of international law, it has a wider significance.

The purpose of this essay is to outline a way of approaching the proliferating literature on globalization and law. It suggests that for any book in the field one needs to ask questions not only about its genre, provenance, and intentions, but also about its conception of globalization and the extent to which it confronts challenges to some widespread assumptions underlying mainstream traditions of Western academic law. Part I below summarizes the central thesis of Domingo's book and analyzes its main themes, Part II outlines an approach to the literature and applies it, by way of illustration, to The New Global Law, and Part III concludes.

\section{THE NEW GLOBAL LAW}

\section{A. OVERVIEW}

Rafael Domingo is a Spanish professor of law with a distinguished record in Roman law, public international law, legal history, and legal theory. His aim in The New Global Law is to set out a vision for a new, just, and stable global order that is coherent and feasible, but does not require a centralized world government. He presents this vision as a specifically juridical contribution to legal science, in particular to what can be called the "science of justice." Domingo's key idea is to substitute the individual human being and humankind for states as the subjects of global law. His aspiration is for a consensual regime of global law limited to issues that affect humanity as a whole and backed by institutions that can make its development and administration democratic, effective, and flexible. This aspiration is explicitly built on the world law tradition of Philip Jessup, C. Wilfred Jenks, Alvaro d'Ors, and Harold Berman. ${ }^{6}$

4. Supra note 1 .

5. Ibid at 160-61.

6. See e.g. Philip Jessup, Transnational Law (New Haven: Yale University Press, 1956); C Wilfred Jenks, The Common Law of Mankind (London, UK: Stevens, 1958); Alvaro d'Ors, La posesion del espacio (Madrid: Civitas, 1998); Harold Berman, Law and Revolution: The Formation of the Western Legal Tradition (Cambridge: Harvard University Press, 1983); Harold Berman, Law and Revolution II: The Impact of the Protestant Reformations on the Western Legal Traditions (Cambridge: Harvard University Press, 2003). 
The first part of the book takes the form of a broad historical overview of the concept of ius gentium " as the solitary source of global law." ${ }^{8}$ Domingo states:

The various garments in which law - fundamentally a mediator of inter-group relationships - has been cloaked throughout history denote the various stages of the science of law, which developed in a particular fashion during the twilight of the Roman Republic and the dawn of the principate. Greek natural law (later developed by Roman jurists and in Christian thought); Roman ius gentium, as the source of inspiration in international relations; medieval ius commune, Islamic Siyar; vernacular variants of modernity, such as the German Völkerrecht, the French droit des gens, or by the sixteenth century, the English "law of nations"; the ius universale, international law, and the interstate law (Staatenrecht) of the rationalist Enlightenment; and more recent descriptors, such as transnational law, the common law of humanity, or the law of peoples - all these mark intellectual efforts directed toward forming a more just intercommunitarian order. ${ }^{\text {? }}$

With foundations in Greek philosophy, the concept of ius gentium can be traced through Cicero, Gaius, and Ulpian; the medieval ius commune; and Grotius, Bentham, and Kant to a regime of law governing relations between states. From the late nineteenth century until recently, public international law has been dominated by European ideas and imperialism. Domingo comments on this phenomenon by saying:

After the Second World War, the conflicts of the Cold War, and the wreckage of September 11, a new global society cries out for a law that can order it according to its new global needs. If the ancient ius gentium served the hegemonic interests of Rome, and international law those of state-based Europe, the new global law, based on the person, must contribute to the common good of humanity and to the development of world peace. The third time is the charm! $!^{10}$

It is clear that Domingo's broad-brush overview is not so much potted history as an attempt to construct a persuasive narrative that shows the continuity of conceptions of ius gentium, each responsive to conditions of time and place, culminating in a new crisis brought about by globalization. Each era needs its own law: Global law is a response to the challenges of globalization.

Part II of the book starts with a critique of the present international order's shortcomings. Globalization challenges strong ideas of sovereignty, territorialiry, precisely defined borders, and above all, states as (almost) the only subjects of

7. Loosely translated as the "law of nations" or the "law of peoples," Domingo traces the changing meanings of the Roman concept of ius gentium through variations on the theme of law common to all (civilized) people, in contrast to ius civile, which is the "law of the city" or "local law."

8. Supra note 1 at xix.

9. Ibid at 4 .

10. Ibid at 195. 
international law. For Domingo, these shortcomings stem largely from treating the state as the foundation of public international law. "Doubtless," he writes, "the 'nation state' was a marriage of convenience that may be justified and certainly had its reason for being. Modernity, however, has witnessed this marriage's plight end in divorce." 11

Domingo argues that in this era of globalization the once useful concepts of territoriality and sovereignty are inadequate as foundations for a just global order. They should be conceived as, at best, subordinate means rather than as ends. $\mathrm{He}$ declares that the United Nations system has proven to be "incapable of meeting the basic security, social, and economic needs of our world." 12 Such institurions, according to Domingo, tend to be hierarchical, bureaucratic, slow-moving, and dominated by a few powers. ${ }^{13}$ What is needed is a new order that avoids these faults without moving in the direction of anarchy or "world domination by economic imperialism or political cryptocracy." ${ }^{14}$ In a forceful analysis of American unilateralism, hegemony, and exceptionalism, Domingo presents American foreign policy and practice both as one of the main obstacles to creating a just global order and as one of the main potential contributors to a new global law. ${ }^{15}$ Despite recent efforts to accommodate human rights, non-state actors, and more permeable borders, international law remains irredeemably state-centric. ${ }^{16}$

Domingo's criticisms are familiar. His approach, however, is radical in that it presents nearly all the weaknesses as flowing from a single idea-that states are (almost) the only subjects of international law. His solution is simple: "The human person, and not the state, should constitute the cornerstone of global law."17

For Domingo, every living human being is a person and, crucially, "[p]ersonhood is recognized, not granted." 18 The juridical phrases "legal person" and "legal personality" obscure the point that only human beings are real persons and that corporations and other entities that are treated as legal subjects belong to "a genus completely different from that of persons." 19 Similarly, animals are not persons. ${ }^{20}$ Humans belong to families, social groups, nations, and, ultimately,

11. Ibid at $\mathrm{xx}$.

12. Ibid at 53 .

13. Ibid at $53-54,61-65,89-90,198-99$.

14. Ibid at xiii.

15. Ibid at 53-54, 89-90, 198-99.

16. Ibid at 54 .

17. Ibid at xvi.

18. Ibid at 126.

19. Ibid at 127.

20. Ibid at 129. 
humankind as an aspirational community. However, the core unit remains the individual human being and this, according to Domingo, should be the basis of global law.

\section{B. THE NATURE AND SCOPE OF GLOBAL LAW}

Domingo categorically rejects the idea of a central world government or global state, which would mark, in his words, "the triumph of imperialism."21 Rather, global law will be configured as an order of consensual fundamental principles of justice and rights that will guide and underpin the development and maintenance of a cohesive legal order within which other legal orders will operate. Global law will be backed by institutions_primarily a legislature and independent judiciary-but its scope will be strictly limited to problems that affect humanity as a whole. ${ }^{22}$ Its rule of recognition or precondition for legitimacy will be "[q]uod omnes tangit, ab omnibus approbetur," or "what affects everyone should be approved by everyone." ${ }^{23}$ Global law will emerge out of, and largely replace, international law. It will differ in being founded on the individual human person and not being confined to relations between states. It will differ from nationstate law in that it will be universal but not total (comprehensive), whereas state legal systems are local but claim comprehensiveness within their territory. "The governance of globalization must be marked by subsidiarity," he insists. ${ }^{24}$ However, according to Domingo, states should not be the only, or even the main, loci of governance at sub-global levels. ${ }^{25}$

Global law is intended neither as a basis for world government nor as a comprehensive legal system, but rather as an agreed framework of principles of justice and rights within which other legal orders should operate. These principles are universal but partial. ${ }^{26}$ Domingo proposes seven principles drawn from a central quasi-Rawlsian ${ }^{27}$ idea of justice to shape all legal orders:

The first three - justice, reasonableness, and coercion - are common to international law as well as global law, for they are part of the law's essence: a law that does not serve justice, that is not rational, or that cannot be imposed coercively is simply not

21. Ibid at 172 .

22. Ibid at xvii.

23. Ibid at 144 .

24. Ibid at 178 [emphasis in original].

25. Ibid at 102, 180-85.

26. Ibid at 272 .

27. See Rafael Domingo et al, Principios de Derecho Global: 1000 reglas y afoísmos juridicos comentados, 2d ed (Cizur Menor: Thomson Aranzadi, 2006). See also John Rawls, $A$ Theory of Justice, revised ed (Cambridge, MA: Belknap Press, 1999) and John Rawls, Justice as Fairness: A Restatement (Cambridge, MA: Belknap Press, 2001). 
law. Together with these, the principles of universality, solidarity, subsidiarity, and horizontality specify the nature of global law. These global principles are opposed respectively to the principles of totality, individuality, centralism, and verticality, which have been the foundation of modern international law. From each of these principles, and especially from the proto-principle of justice, are derived many others - the principles of property, security, legality, proportionality - that can also affect global law. ${ }^{28}$

Domingo devotes nearly fifty pages to expounding his own interpretations of these principles and proto-principles, an interesting elaboration of a personal position that is heavily influenced by both Roman law and Catholic doctrine. ${ }^{29}$ This concretizes his argument and provides plenty of material for critical discussion. What is interesting for present purposes is the idea of gaining agreement on quite extensive working precepts as a basis for devising a new set of supra-national institutions, including a global parliament and a global tribunal, both with limited jurisdiction. ${ }^{30}$ The global parliament will take responsibility for regulation, in whole or in part, of those issues that affect humanity as a whole and, to that extent only, will limit the sovereignty of states and other legal orders. Domingo cites the Universal Declaration of Human Right ${ }^{31}$ as a rare example of the international community taking a major step beyond traditional international law; ${ }^{32}$ one may infer that he hopes that a similar consensus based on his foundational principles might be reached-possibly after a major crisis. He states:

The reader must not confuse global law with a closed legal system or juridical order, let alone a mere collection of more or less binding and sterile rules. Rather, it would be a system of systems, a iuris ordorum ordo, which necessarily would develop into an ordo orbis as it is gradually accepted by all communities and citizens of the world. Its purpose would be similar to that of the sun in the solar system that is mostly composed of planets but also of billions of smaller bodies: asteroids, meteorites, comers, and so on. ${ }^{33}$

Domingo posits that global law should be limited to genuinely global issues. He says, "I understand global law to be the world legal order that governs the ambit of justice as it affects humanity as a whole." ${ }^{34}$ The scope of global law includes "the prorection of human rights; the maintenance of peace in the world;

28. Supra note 1 at 157-58.

29. See Domingo et al, supra note 27.

30. Supra note 1 at $35-36,145-46$.

31. GA Res 217(111), UNGAOR, 3d Sess, Supp No 13, UN Doc A/810, (1948) 71.

32. Supra note 1 at 36 .

33. Ibid at xvii.

34. Ibid. 
the trial of international criminals; the regulation of arms, the environment, and international commerce; the eradication of poverty are issues that affect everyone and should be addressed by humanity as a whole." ${ }^{35}$ How global law can be strictly limited to such issues would likely present some challenges in pracrice.

Domingo's carefully constructed theory of global law avoids some of the pitfalls facing such efforts. He is not proposing a global state or a mere extension of international law or a closed legal system, which claims comprehensiveness; nor is he proposing universal jurisdiction or even a sharp break with existing legal traditions. The principles on which this new kind of legal ordering would be based would not be derived from any one belief system or ideology, but rather would draw upon (without incorporating) natural law and different religious, philosophical, and legal traditions.

\section{DOMINGO AND RAWLS}

Domingo draws extensively on Rawls's theory of justice and defines aspects of his position in contrast to him. Both are concerned with constructing a "realistic Utopia" ${ }^{36}$ based upon principles of justice; both are concerned with the methodology of what Domingo calls the "science of justice;" 37 and both emphasize equality and liberty as primary values, but in different ways. For example, Domingo, following Hart, rejects the priority of liberty. ${ }^{38}$ Both Domingo and Rawls favour social pluralism-the co-existence of political communities based on different religions, cultures, and arrangements..$^{39}$ Domingo accepts Rawls's two principles of justice as glossed by Alexy. ${ }^{40}$ However, Domingo characterizes his perspective as legal rather than political, ${ }^{41}$ a distinction that is open to challenge.

Domingo and Rawls differ on the concept and role of the human person in a theory of a just order:

The major difference between John Rawls's theory and the global principles I propose is that Rawls's point of departure is the idea of a "moral person," whereas mine is the person himself as a bearer of rights (the nomophor). His reinterpretation

35. Ibid at $144-45$.

36. Ibid at 41.

37. Ibid at 160-61.

38. Ibid at 161 .

39. Ibid at 184 .

40. The two principles proposed by Alexy for resolving possible tensions between equality and freedom, are (a) if there is no justified reason to require differential treatment, it is necessary to seek undifferentiated treatment and (b) if there is a justified reason to seek differential treatment, then such special treatment can be demanded. Ibid at 141 .

41. Ibid at 101 . 
of Rousseauian ideas about persons (men as they are), with their application first to institutions and ultimarely to peoples, is central to our differences. ${ }^{42}$

Three points underline the significance of this difference. First, Domingo's conception of personhood leads to a much greater emphasis on individual rights. Second, Rawls's conception of peoples is only a short step away from his concepts of nation and state. For Domingo, the only closed society is humankind and his idea of political communities is much broader and more flexible than Rawls's. ${ }^{43}$ Third, Domingo takes globalization seriously in a way that Rawls does not. ${ }^{44} \mathrm{His}$ conception of a just global order is significantly different from Rawls's Law of Peoples and he can be exempted from much of the criticism that this aspect of Rawls's thought has attracted. ${ }^{45}$

Despite these differences, Domingo's theory of global law belongs to the same genre as Rawls's theory of justice: It is a transcendental, universalist design theory providing a basis for ideal just institutions. Within Western thought, it belongs to the tradition of Kant and Locke rather than Bentham, Mill, and Hart. Whether this makes him vulnerable to Amartya Sen's critique of transcendental institutionalism will be considered below, in Part II Secrion B.

This brief summary should suffice to give an overall picture of Domingo's vision and its connection with some familiar strands in Western academic law, in particular Roman law, the development of the Western legal tradition, natural law (especially in its contemporary Catholic version), human rights, and contemporary international law. It is broadly in tune with liberal-democratic theory. ${ }^{46}$ There is, of course, plenty that may be contested on particular points within the liberal-democratic tradition. Domingo is, for instance, sharply dismissive of Anglo-American positivism even though he draws some ideas from Hart. As well, issues might be raised about rights-based approaches, subsidiarity, American exceptionalism, constitutionalism, and so on. Rather than engaging with such issues here, I shall consider the value and limitations of this general kind of proposal from a global perspective. Writing about globalization and law is proliferating exponentially. The purpose of the next part is to suggest one way of locating

42. Ibid at 42 [emphasis in original].

43. See e.g. ibid at 115-20.

44. See Amartya Sen, The Idea of Justice (Cambridge: Harvard University Press, 2009) at 24-26.

45. See e.g. Allen Buchanan, "Rawls's Law of Peoples: Rules for a Vanished Westphalian World" (2000) 110 Ethics 697; Thomas Pogge, "Rawls on International Justice" (2001) 51 Phil Qrtly 251; Ibid; and Twining, GJP, supra note 1 at 159-67.

46. Supra note 1 at 157. Domingo's values are close to the cosmopolitan principles of David Held. See e.g. David Held, Global Covenant: The Social Democratic Alternative (Cambridge, UK: Policy Press, 2004). 
and assessing any contribution to this literature, using The New Global Law to illustrate the approach.

\section{A CONTEXTUAL APPROACH TO THE NEW GLOBAL LAW}

The proliferating literature on globalization and law hardly respects boundaries between the two disciplines. ${ }^{47}$ Although he acknowledges his debt to philosophers and theologians, Domingo gives more than a hint that he assumes some notion of the autonomy of disciplines. In any case, nearly all of his references are to legal writers. Although the distinction between disciplines is artificial, it is convenient here to focus on writings about globalization and law by legal scholars. ${ }^{48}$ In this context, one can roughly distinguish between several different kinds of work: some as contributions to legal theory $;^{49}$ some as examples of rethinking or internal critique within a transnational field; ${ }^{50}$ some as specialist contributions to emerging transnational fields; ${ }^{51}$ some as explorations of the impact of globalization or transnationalization of fields previously considered to be exclusively domestic; ${ }^{52}$ some as writings from a "southern" perspective; ${ }^{53}$ and some as treatises on special topics that have become more salient. ${ }^{54}$ There is, of course, also a vast literature

47. Various specialists have written on the topic of law and globalization including sociologists, philosophers, political scientists, economists, and historians as well as multi-disciplinary works. See e.g. de Sousa Santos, supra note 3; Peter Singer, One World: the ethics of globalization, 2d ed (New Haven: Yale University Press, 2004); Robert Keohane \& Joseph Nye, Power and Interdependence, 3d ed (Glenville: Longman, 2001); Joseph Stiglitz, Globalisation and its Discontents (New York: WW Norton, 2002); Lauren Benton, Law and Colonial Cultures: Legal Regimes in World History 1400-1900 (Cambridge, UK: Cambridge University Press, 2002); Jonas Ebbeson \& Phoebe Okowa, eds, Environmental Justice in Context (Cambridge, UK: Cambridge University Press, 2008).

48. There is also a growing body of practitioners' works that is not discussed here and a body of writings that develop a particular perspective, such as feminism or post-modernism, that cuts across traditional academic fields.

49. See e.g. Brian Tamanaha, $A$ General Jurisprudence of Law and Society (Oxford: Oxford University Press, 2001).

50. See e.g. Pierre Legrand \& Roderick Munday, eds, Comparative Legal Studies: Traditions and Transitions (Cambridge, UK: Cambridge University Press, 2003).

51. See e.g. Oren Gross \& Fionnuala Ni Aolain, Law in Times of Crisis: Emergency Powers in Theory and Practice (New York: Cambridge University Press, 2006).

52. See e.g. Franklin A Gevurtz, ed, Global Issues Series (St Paul: West Academic, 2006).

53. See e.g. Balakrishnan Rajagopal, International Law from Below (Cambridge, UK: Cambridge University Press, 2003); William Twining, ed, Human Rights: Southern Voices (Cambridge, UK: Cambridge University Press, 2010).

54. See e.g. Christopher McCrudden, Buying Social Justice: equality, government procurement and legal change (Oxford: Oxford University Press, 2007). 
on regional law and regimes. These examples, which are far from comprehensive, are enough to show that this literature defies neat caregorization. ${ }^{55}$

\section{A. LOCATING DOMINGO WITHIN THE LAW AND GLOBALIZATION LITERATURE}

A good place to start is to ask, "Where is the author coming from and what is his or her conception of the enterprise?" In Domingo's case the answer is reasonably clear. We have seen that his academic background is in civil law, Catholic natural law, and mainstream public international law, explicitly building on the World Law legacy of Jessup, Jenks, and d'Ors. He draws extensively on his knowledge of Roman law. He writes as a jurist and presents his book as a contribution to the "science of justice," ${ }^{6}$ which approximates to the Anglo-American category of normative jurisprudence. He acknowledges the relevance of neighbouring fields, especially political theory and international relations, but treats them as distinct disciplines. ${ }^{57}$

A second preliminary question is, "What is the author's conception of globalization?" Domingo can hardly be accused of "global neglect," ${ }^{58}$ but he does not explicitly discuss different conceptions and controversies about the nature of globalization. Nevertheless, it is fairly easy to identify the outlines of his position on these matters.

First, he adopts a broad and relatively neutral conception of globalization as extending beyond politico-economic relations to include technology, communications, environment, disease, terrorism, peace, and justice. In this view, globalization is a complex social fact rather than just the kind of economic

55. Perhaps more significant is the fact that all of these examples are from the English language literature. The New Global Law is a relatively rare example of a contemporary work about globalization and law in a European language that has been translated into English. This essay is linguistically parochial, but I hope that the approach suggested here can also be applied to non-Anglophone works. This limitation is due to ignorance and I can only claim familiarity with about a half-dozen or so relevant works, mainly in French or Italian.

56. Supra note 1 at $160-61$.

57. Domingo exhibits no interest in empirical legal studies and is dismissive of utilitarianism and legal positivism. However, he does engage with Kelsen and Hart. Of contemporary theorists writing about globalization and law, he cites Harold Berman and Patrick Glenn but makes no reference to Paul Berman, de Sousa Santos, Tamanaha, Teubner, Trubek, or Twining. Interestingly, he largely ignores the writings of public international lawyers who seek to rethink or to reform public international law from within-even the more radical ones such as Allort, Capaldo, Franck, David Kennedy, or Koskenniemi. Nor does he cite one of the most vociferous critics of the current international order, Rawls's pupil-turned-critic, Thomas Pogge. This list of omissions is not intended as criticism-engaging with most of these would surely have cluttered the book.

58. Sen, supra note 44 at $24-27,138-41$. 
hegemony that has been the target of the anti-globalization movement. Second, global law is genuinely global, at least in aspiration, in that it applies and is restricted to the world as a whole. Domingo does not fall into the trap of using global to mean widespread or important, or merely transnational. ${ }^{59}$ Third, Domingo's gaze is focused consistently at the global level on issues that actually or potentially affect humankind generally. He treats detailed problems and dilemmas about the practical operation of subsidiarity at sub-global levels as beyond his remit and he does not go into detail about criteria for determining which matters are best dealt with primarily at the global level. However, he is clear that the scope of global law is quite restricted.

Thus, Domingo steers clear of most of the traps involved in the overuse and misuse of "global," "globalization," and like terms. However, like many orhers, he tends to see the world in terms of neatly layered, essentially concentric patterns. He talks loosely of vertical and horizontal levels of governance and of moving from the local to the global. ${ }^{60} \mathrm{He}$ uses an analogy with geology to depict his total picture of human relations and the principle of subsidiarity:

A basic geological principle of original horizontality, according to which layers of rock are first deposited horizontally in an arrangement that remains fixed so long as no other force acts upon it. This same principle can be applied to the law because humanity also comprises different levels: personal, familial, local, regional, national, continental, and global. We must maintain this distribution, limiting as much as possible the use of force on its layers. ${ }^{61}$

This is probably overly simple as geology; it is quite misleading in respect of law. Our heritage of legal phenomena is much messier than that. Some of the most significant patterns relating to law are sub-global: the legacies of empires, diasporas, alliances, trading blocs, language spread, legal traditions, criminal networks, and so on. Consider, for example, the French empire, the Islamic umma, NATO, NAFTA, the G8, OPEC, ASEAN, and Al Qaeda. These do not fit neat geometrical metaphors of concentric circles, vertical hierarchies, horizontals, or diagonals, nor geological analogies of strata, layers, or levels. Rather, they are interrelated, interacting, diffusing, and crisscrossing in extremely complex ways. Crucially, all these examples are sub-global. There

59. However, see supra note 1 at 172 where he does say, "English is the most universal language." To talk of English as the global or a universal language is descripcively an exaggeration; it may be for the time being the most used in certain kinds of transnational relations, but only a small proportion of the world's population (at most $10-15$ per cent) have a working knowledge of it. However, in the context, Domingo's point is that global law is, like English, universal, but partial or, in his own words, "neither total nor absolute" at claiming exclusivity or dominance (ibid).

60. See e.g. supra note 1 at xiii, 149, 182.

61. Ibid at $\mathbf{1 8 2 .}$ 
never has been a world empire, a world language, a single world legal tradition, or even a genuinely global war. Political communities, multiple individual identities, and hybrid cultures are intimately related to such disorderly and elusive patterns. Attempts to design workable global and transnational institutions must surely be based on a sense of history and on information that takes into account such complexities. From this perspective, Domingo's "new pyramid of law" 62 looks rather too neat.

\section{B. IDEAL THEORY AND PRACTICALITY}

In 2009, Amartya Sen launched a powerful critique of transcendental institutionalism, using Rawls as his main target. According to Sen, Rawls's theory of justice is an arrangement-focussed rather than a realization-focussed theory concentrating on possible transcendentally just institutions rather than being concerned with reducing obvious injustice in the actual world in which we live. Just institutions often produce unjust results in practice. ${ }^{63}$ Sen's concern is with a tradition of philosophizing and economic theory that is too abstract and removed from what actually happens. ${ }^{64}$

As we have seen, Domingo claims to be close to Rawls. He also claims to be realistic. Domingo is concerned with making a contribution that is practical. He stresses that his vision is of a legal regime that is possible, not merely Utopian. ${ }^{65}$ It does not require revolution, but rather it will evolve out of existing traditions ${ }^{66}$ and arrangements, ${ }^{67}$ thereby maintaining continuity. Nevertheless, his is a design theory focusing on an idealized global law as a desirable end-state for a just order rather than providing practical guidance on solutions to immediate problems of justice and injustice or a route map on how to move forward from the present unsatisfactory state of affairs.

62. See ibid at 147-53.

63. Sen, supra note 44 at 75-81. The crux of Sen's critique of this kind of ideal theory is summed up as follows: "There are ... good evidential reasons to think that none of these grand institutional formulae typically deliver what their visionary advocates hope, and their actual success in generating good social realizations is thoroughly contingent on varying social, economic, political and cultural circumstances" (ibid at 83 ). Sen's plea is "for constant sensitivity to what actually happens in the real world" (ibid).

64. Sen's objection is nor that transcendental theory is valueless or uninteresting, but rather that too much philosophical effort has been diverted from making useful contributions to pressing real-world problems that are soluble. Put crudely, from a practical point of view, ideal theory is neither necessary nor helpful. Ibid at 24-27.

65. Supra note 1 at $41,147$.

66. Ibid at 195 .

67. Ibid at xviii. 
Domingo does not cite Sen, whose The Idea of Justice $e^{88}$ was published only shortly before the English translation of The New Global Law. From now on, anyone concerned with justice and injustice needs to take account of Sen's critique of Rawls and of his alternative vision. To be fair, Domingo cannot be accused of "global neglect" - a charge laid by Sen against many philosophers-and his account of global law is much more carefully worked out and persuasive than Rawls's very disappointing Law of Peoples. Moreover, he rejects Sen's view that "an impeccably just set of institutions, even if such a thing could be identified, would certainly demand a sovereign global state." ${ }^{69}$ My own view is that Domingo does provide a vision of one possible aspiration and some ideas (e.g., some of his regulae) that might be useful as working principles in negotiations towards a reasonable political settlement. Nevertheless, his book and similar works are vulnerable to Sen's critique of transcendental institutionalism: We have to deal with the world as we find it.

\section{THREE SCENARIOS FOR THE FUTURE OF LAW IN THE WORLD}

Domingo, like many others, is advancing proposals for the future. In an interesting exercise on "Law of the Future and the Future of Law," the organizers of a recent conference hosted by the Hague Institute of International Law (HiiL) have proposed three possible scenarios that could represent dominant patterns of law in the world in thirty years' time. ${ }^{70}$ These are not so much predictions as indicators of a range of plausible possibilities extrapolated from recent trends. The authors' starting point is the observation that there have been two major shifts in the contemporary global legal environment: (a) from a predominantly national to a predominantly international legal environment and (b) from a predominantly public legal regime to a mixed public-private regime or even a predominantly private regime. ${ }^{71}$ On the basis of this view, they envisage three broad scenarios.

\section{GLOBAL CONSTITUTION}

The first question regarding the future global legal environments is whether international rules and institutions further expand or not. If the expansion of international nules and institutions continues, we may expect that the legal order will slowty develop as the European Union [EU] has been developing: into a nobust legal order of its own, highly integrated with national legal systems.

68. Sen, supra note 44 .

69. Ibid at 25.

70. Sam Muller et al, The Law of the Future and the Future of Law (Oslo: Torkel Opsahl Academic EPublisher, 2011).

71. Ibid. 


\section{LEGAL BORDERS}

If, on the other hand the process of expansion of international rules and institutions reverses, we may expect a thickening of legal borders instead, which will then, almost by definition, be dominated by state-made law (at national or regional level). This world will probably see regional organisations emerging as part of the development of legal borders aimed at warding off the global legal environment.

\section{LEGAL INTERNET}

But, international rules and institutions can also further expand as part of a process of shifting emphasis from law created and enforced by state-connected institutions to private governance mechanisms and private legal regimes. If they do, the global legal environment will be characterised by a growing body of international rules and institutions with an increasingly public-private or even private nature. ${ }^{72}$

The starting point may be controversial and the scenarios quite speculative. A mixture of all of them is not an improbable outcome. Bur, as ideal types, these are a useful device for characterizing different visions of the future of law and prescriptions for legal development. Domingo would almost certainly accept the first premise-a shift from a predominantly national to an international legal environment-but might be less emphatic about a major shift to private legal ordering. His conception of global law clearly firs the first scenario better than the others, except that his global law would be independent of public international law and would give less prominence to national/state legal systems. He does not envisage a retreat towards protectionism and strengthened borders. Although he sees lex mercatoria and arbitration as playing a significant role in the development of global law, ${ }^{73}$ his vision fits much more closely the public law scenario. This, interestingly, puts him in the same general area as Boaventura de Sousa Santos ${ }^{74}$ - a very different thinker who envisages the future of law as a struggle between hegemonic and counter-hegemonic forces and whose hope is for a global constitution based on democracy and human rights. As a way of broadly characterizing visions for the future of law, the HiiL scenarios are useful, but there are, of course, other more pessimistic or untidy possibilities.

72. Sam Muller et al, Law Scenarios to 2030: Signposting the legal space of the future (The Hague: Hague Institute for the Internationalisation of Law, 2011).

73. Supra note 1 at $17-18,112$.

74. Supra note 3. 


\section{SOME CHALLENGES OF GLOBALIZATION}

I have argued elsewhere that globalization challenges a number of widespread but not universal assumptions that underpin mainstream Western traditions of law. ${ }^{75}$ Pinpointing some of these assumptions provides a template for analyzing any contribution to inquiries and debates about globalization and law. My list is as follows:

- that law consists of two principal kinds of ordering: municipal state law and public international law-the Westphalian duo;

- that nation-states, societies, and legal systems are largely closed, self-contained entities that can be studied in isolation;

- that modern law and modern jurisprudence are secular and now largely independent of their historical cultural roots in the JudaeoChristian traditions;

- that modern state law is primarily rational, bureaucratic, and instrumental, performing certain functions and serving as a means for achieving particular social ends;

- that legal phenomena are best understood through "top-down" perspectives of rulers, officials, legislators, and elites with the points of view of users, consumers, victims, and other subjects being at best marginal;

- that the main subject matters of the discipline of law are ideas and norms rather than the empirical study of social facts;

- that the modern state law is almost exclusively a Northern (European/ Anglo-American) creation, diffused through most of the world via colonialism, imperialism, trade, and latrer-day post-colonial influences;

- that the study.of non-Western legal traditions is a marginal and unimportant part of Western academic law; and

- that the fundamental values underlying modern law are universal, although the philosophical foundarions are diverse.

This template, or something like it, can be used to test the relevance of globalization to one's own work. The interested scholar can ask, "To what extent do I, in my work, make working assumptions like these, and to what extent should these assumptions be re-examined in the light of globalization?"

75. Twining, GJP, supra note $\mathbf{1}$ at $5-7$. For a work addressed to the individual scholar, see also Twining, GLS, supra note 1. My list was constructed from my study of the area and forms the backbone of Twining, GJP, supra note 1 . It does not claim to be comprehensive or systematic and any scholar can vary it according to his or her own perspective. Resisting one or more such challenges is always an option. 
In addition to advancing the cause of self-critical legal studies, it can be used to assess how far an author or a particular work has addressed, or adjusted to, challenges presented by globalization. How does The New Global Law fare in relation to these propositions?

\section{THE WESTPHALIAN DUO}

Domingo explicitly rejects the assumption underlying the theories of the great majority of Western jurists that there are only two kinds of law: the municipal law of sovereign states and public international law in the classic sense of the law governing relations between states. State centrism and strong conceptions of sovereignty are among his principal targets. He explicitly recognizes nonstate law. ${ }^{76}$ His idea of global law is sui generis, conceptually distinct from public international law. ${ }^{77}$ He treats lex mercatoria and some kinds of religious laws and custom as law, but he does not set out specific criteria of identification to distinguish legal norms from social norms or legal orders from other normative orders. He emphasizes Christian canon law as a source of inspiration for global $\operatorname{law}^{78}$ and acknowledges Islamic law somewhat perfunctorily. ${ }^{79}$ Thus, Domingo works with a broad conception of law but is not unduly concerned about the borders of the concept. ${ }^{80}$

It is widely accepted in the jurisprudential literature that to extend the concept of law to include, at least, some forms of non-state law leads in practice, if not as a matter of logical necessity, to acceptance of the idea of legal pluralism, that is of independent or semi-autonomous institutionalized normative orders that co-exist in the same time-space context and satisfy some broad conception of law. ${ }^{81}$ Domingo mounts a powerful attack on state centralism especially in respect of confining law to nation-state law and restricting international law to relations between states. He is in favour of cultural diversity (social pluralism) and deplores the homogenizing tendencies of globalization. ${ }^{82}$ But, he barely discusses normative and legal pluralism. Perhaps wisely, he skirts around controversies about

76. See e.g. supra note 1 at 109-10.

77. Domingo does not explicitly treat European Union law as sui generis. For a treatment of EU law as sui generis, see e.g. Neil MacCormick, Questioning Sovereignty (Oxford: Oxford University Press, 1999) ch 9.

78. Supra note 1 at $18-19$.

79. lbid at 19-21.

80. On the limited importance of general definitions of law, see Twining, GJP, supra note 1, ch 4 .

81. William Twining, "Normative and Legal Pluralism: A Global Perspective" (2010) 20 Duke J Comp \& Int'l L 473.

82. Twining, GJP, supra note 1 at 184 . 
conceptualizing law. ${ }^{83}$ On non-state law, he cites Selznick, ${ }^{84}$ Ehrlich, ${ }^{85}$ and Santi Romano $^{86}$ seemingly with approval, but he does not explore or even acknowledge the much richer and more complex pictures of legal phenomena that emerge from the mainstream literature on normative and legal pluralism. From this perspective, Domingo's picture of law in the world again seems much too neat.

\section{STATES AND LEGAL SYSTEMS AS SELF-CONTAINED UNITS}

Domingo does not treat nation-states as closed, self-contained units. In this respect he moves significantly beyond Rawls. ${ }^{87}$ Part of his thesis relates to the erosion of sovereignty and the threat to the nation state, but states based on countries will survive as one kind of political community among others. ${ }^{88}$

\section{SECULARISM}

Secular can mean non-religious, unreligious, or even anti-religious; it can also mean independent from religion, as in the idea of a secular state mediating between diverse belief systems and religious institutions or establishments. Domingo is quite explicit:

Global law is common and secular. It is common insofar as it potentially pertains to every human being. It is also common by being compatible with the law specific to each people and political community. And it is secular because the sources of law are not religious. ${ }^{89}$

A religious or confessional law is not global. However, religious traditions can contribute significantly to the development of global law. ${ }^{90}$ Freedom of

83. However, see Rafael Domingo, Auctoritas (Barcelona: Ariel, 1999).

84. Supra note 1 at 109 .

85. Ibid at 109 .

86. Ibid at 128 .

87. Sen criticizes Rawlsian principles of justice for a number of "seriously problemaric exclusions" including "[i]gnoring the possibly adverse effects on people beyond the borders of each country from the actions and choices in this country, without any institutional necessity to hear the voices of the affected people elsewhere." Sen, supra note 44 at 90.

88. Domingo, supra note 1 at 109-10,122.

89. Supra note 1 at 193 .

90. For example, Domingo states:

In the formation of a global law, canon law contributes more than almost anything else: the principle of personhood against that of the state's territoriality, an appropriate combination of the common and the local, a respect for legal sources not strictly legislative, and clear support for principles and rules. In addition, it is a legal system that suffered none of the serious consequences of radical legal positivism derived from excessive state involvement in juridical decisions. Ibid at 18-19. 
religion is a first principle of global law. ${ }^{91}$ Domingo does not discuss the phenomenon of contemporary religious revival, but he does not believe, as some do, that we live in "a secular age." Clearly, he is strongly influenced by his Catholicism. He draws extensively on canon law and papal encyclicals as sources of inspiration, but he also acknowledges the contributions of Greek, Roman, and medieval ideas to the past development of law and the potential contribution of other religions. His book contains almost no serious discussion of other religion-based orders.

\section{INSTRUMENTALISM}

Domingo is far from being a crude instrumentalist. ${ }^{93} \mathrm{He}$ rejects utilitarianism and technocracy. ${ }^{94}$ His perspective is imbricated throughout with concerns for justice and moral values.

\section{TOP-DOWN PERSPECTIIVES}

Domingo's emphasis on subsidiarity and his insistence that the ultimate source of law is individual human beings support his claim that he rejects "top-down perspectives. ${ }^{95} \mathrm{His}$ spirit is democratic and pluralist. ${ }^{96}$ However, his point of view is quite distant from those of victims, users, the poor, and the oppressed, who see law in terms of other people's power, or of commentators who, in adopting "subaltern" perspectives, present human rights and freedom as the achievement of struggles rather than the gift of Western intellectual traditions. ${ }^{97}$

So far, subject to a few caveats, Domingo appears to have gone a long way towards responding to the first five challenges that globalization presents to Western traditions of academic law. The picture changes substantially in respect of the next four challenges.

91. Ibid at 135.

92. See Philip Jenkins, The Next Christendom: The Coming of Global Christianity (Oxford: Oxford University Press, 2007); Charles Taylor, A Secular Age (Cambridge: Harvard University Press, 2007).

93. Brian Z Tamanaha, Law as a Means to an End: Threat to the Rule of Law (New York: Cambridge University Press, 2006); Twining, GJP, supra note 1, ch 16.

94. Supra note 1 at 184-85.

95. Ibid at 180 .

96. Ibid at 180-85.

97. See e.g. Upendra Baxi, The Future of Human Rights, 2d ed (New Delhi: Oxford University Press, 2006); Balakrishnan Rajagopal, International Law from Below: Development, Social Movements, and Third World Resistance (Cambridge, UK: Cambridge University Press, 2003). 


\section{IDEAS AND NORMS VERSUS EMPIRICAL STUDY OF FACTS}

A crude but quite effective way of characterizing differences within Western traditions of academic law is to suggest that nearly all legal theory and legal scholarship can be located on a continuum stretched between two ideal types or poles: One pole conceives of understanding law as being limited to doctrine (concepts, rules, principles, et cetera) and the other pole focuses on the actual operation of legal rules, institutions, processes, actors, techniques, and consequences in the real world. Of course, sharp contrasts between doctrinal and empirical perspectives or between the law in books and the law in action easily descend into caricature. Few doctrinal scholars are totally indifferent to enforcement, consequences, and what happens in practice; few, if any, empirical legal scholars believe that concepts, rules, and principles are unimportant. Nevertheless, there are very significant differences (not just in emphasis) along this continuum and some of them are not obvious on the surface. For example, the leading figures in current debates in Anglo-American legal philosophy (such as Hart, Dworkin, Raz, and Finnis) are all very close to the doctrinal pole in that they assume that understanding law is almost entirely a matter of understanding norms (concepts, rules, principles, et cetera) of municipal legal systems (or the Westphalian duo). ${ }^{98}$ This has been the dominant strand within Western traditions of academic law. Assumption 6 on my list suggests that if one adopts a global perspective this dominance should be challenged. To put it simply, law is a social phenomenon and all legal systems are shaped by their political and economic context. It is not necessary here to engage in the controversies surrounding these views. ${ }^{99}$

It is clear that Domingo is quite close to the doctrinal pole although he recognizes the importance of institutions and enforcement. We have already seen in the discussions of globalization, Sen's critique of Rawls, and legal pluralism that Domingo's vision and his conception of legal science is vulnerable to the

98. For a major exception, which is more open to issues of transnationalization and globalization and to the idea of non-state law than most contemporary analytical legal philosophers have been to date, see Neil MacCormick, Institutions of Law: an Essay in Legal Theory (Oxford: Oxford University Press, 2007). See also Makysmilian Del Mar \& Zenon Bankowski, eds, Law as Institutional Normative Order (Farnham: Ashgate, 2009).

99. Perhaps Montesquieu and Adam Smith deserve to be recognized as the classic Western forerunners of this alternative tradition. See especially Charles Secondat \& Baron de Montesquieu, The Spirit of the Laws, translated by Thomas Nugent (Berkeley: University of California Press, 2003); Adam Smith, Lectures on Jurisprudence by R Meek, PG Stein \& DD Raphael (Oxford: Oxford University Press, 1978). On Adam Smith as a forerunner of contextual approaches to law, see Neil MacCormick, Legal Right and Social Democracy (Oxford: Clatendon Press, 1982) ch 6. 
criticism that he underestimates the complexities of legal phenomena and of existing sub-global patterns of our heritage of law and does not get to grips with the practical difficulties of achieving consensus and reducing injustice.

\section{EUROCENTRISM AND ETHNOCENTRISM}

There is a quite widespread tendency to see both international law and the contemporary bureaucratic states as European creations, diffused through the world largely by colonialism, imperialism, trade, and neo-colonialism. Domingo explicitly recognizes classical public international law as a Eurocentric creation ${ }^{100}$ and argues that global law must develop away from this. He does not say much about the diffusion of law, surely now a central topic in considering law from a global perspective. He acknowledges his European training and education but claims not to be Eurocentric. ${ }^{101}$

None of us can escape entirely from our intellectual roots and Domingo aspires to adopt a genuinely global perspective. However, some will feel that his interpretations of history, his treatment of religions other than Christianity, and his very limited acknowledgement of non-Western legal traditions suggest that he has not escaped very far. His argument suggests that global law, for the benefit of all humankind, will evolve out of an essentially European heritage, including building on the EU, without much reference to the interests, views, cultures, and traditions of the rest of the world (with the possible exception of the United States provided that it abandons its unilateralist and exceptionalist pretensions). That is a recognizable point of view, but it hardly represents a genuinely global perspective.

\section{UNIVERSALISM AND BELIEF PLURALISM}

Underlying Western traditions of law are some very strong strands of universalism in ethics: Natural law, Kantianism, utilitarianism, and some theories of human rights have been universalist in tendency, claiming to apply to all human beings at all times and in all places. Of course, universalism is an elusive concept, ${ }^{102}$ but most such theories allow some space for particularities of culture, conditions, and traditions. However, if one adopts a genuinely global perspective, one is confronted with an almost inescapable fact: ${ }^{103}$ There exists a diversity of belief systems, cosmologies, values, and ethical views that are extensive, deep-rooted,

100. See e.g. supra note 1 at 25.

101. Ibid at xxiii.

102. Twining, GJP, supra note 1 at 127-29.

103. I say "almost" because there are some who believe that the existence of universal values and beliefs can be demonstrated empirically. I do not enter into this controversy here. 
and not likely to be amenable to forming the basis for a consensus arrived at by rational debate and persuasion. ${ }^{104}$ If one accepts that such belief pluralism exists and is unlikely to change in the foreseeable future, then one of the major challenges facing humankind is how to construct frameworks, institutions, processes, and norms that support co-existence and co-operation to a reasonable extent. Put thus, the way forward looks more like a political process of negotiation and settlement than like an arrival at a consensus on values and principles.

Any work that seeks to present recommendations about the future ordering of the world has to confront this problem and, indeed, a great deal of contemporary Western ethical and political theory treats it as a central concern. It is not entirely easy to locate a thinker like Domingo in relation to this. He has his own religious and ethical commitments, but he recognizes that these cannot, on their own, be the basis for his argument. He seems quite optimistic about reaching a strong, if not universal, acceptance of his foundational principles of global law and he can point to the Universal Declaration of Human Rights and the Millennium Development Goals, ${ }^{105}$ among others, as examples of such achievements, despite the cynicism that they attract in some quarters.

\section{CONCLUSION}

The purpose of this essay has been to illustrate one way of getting to grips with the growing literature on globalization and law. The New Global Law is in many ways an admirable book. It is a reflective, coherent, clear, and forthright statement of a possible scenario for the future of law in the world, which many may find attractive - a new world legal order built on principles of dignity and justice with limited central institutions and clear guidelines and meeting (a) some major criticisms of the present regime of institutions and public international law; (b) an alternative to anarchy, or imperial domination, or kleptocracy; and (c) a carefully thought out but flexible body of guiding principles as a basis for discussion or negotiation. The New Global Law provides illuminating links to Roman law scholarship and contemporary continental thought about globalization that is not available in English. If some of my analysis suggests that it fails to confront some of the challenges of globalization to our heritage of legal scholarship, this signals limitations that are widely shared by a literature that generally underestimates the extent and significance of these complex and bewildering processes.

104. Twining, GJP, supra note 1 at 131.

105. Supra note 1 at 36. 
